\title{
OTUD5 Gene
}

National Cancer Institute

\section{Source}

National Cancer Institute. OT UD5 Gene. NCI Thesaurus. Code C124952.

This gene plays a role in both protein deubiquitination and immune system regulation. 